\title{
Management of pain in the immediate post- operative patient with patients submitted to general anesthesia
}

\begin{abstract}
Introduction: Pain causes suffering, distress and poor quality of life, may be associated with emotional, spiritual or present damage, is one of the most common causes of the doctor's search, and may be responsible for the increase in postoperative complications. Due to the need to treat discomfort in the postoperative period, criteria were defined to assess the degree of pain, such as the application of a verbal numeric rating scale, where patients are asked to rate the level of their pain.
\end{abstract}

Objective: to describe pain management in adult patients with visual analogue scale (VAS) submitted to general anesthesia.

Methodology: This is a study of narrative bibliographic review. The present research analyzed scientific articles in the LILACS and SciELO database. For this study, articles from 2012 to 2016 were included, with full text availability and free electronic media, in the Portuguese language, that addressed the topic of Pain Management in the postoperative period.

Results: 10 studies were identified, and the content was analyzed according to the theme. Final considerations: Based on the results, the important role of the nursing team in the adequate management of pain is highlighted. The multidisciplinary team must participate in an active and humanized way in the treatment. It is recommended to value the subjectivity of the patient's report taking into account their complaints and requests, it is necessary to develop bonds of trust and communication with the patient, besides the evaluation of the biopsychosocial state, because at this moment the patient is fragile.

Keywords: pain, analgesia, post-operative care, analogic visual scale, anesthesia
Volume 9 Issue 2 - 2017

\author{
Oliveira Junior, Nery José Rivers, Jessica \\ Petry Stachelski, Mariana Fachi \\ Master in Nursing, Lecturer at the FADERGS University Center, \\ Member of the Center for Nursing Management Studies \\ (NEGE), Brazil
}

\begin{abstract}
Correspondence: Nery José de Silva, Master in Nursing, Lecturer at the FADERGS University Center, Member of the Center for Nursing Management Studies (NEGE), Avenida Jacuí 638/3 II, Cristal, 908I0-150, Porto Alegre, RS, Brazil, Tel (5I) 21। I3966,Email nery.oliveirajr@gmail.com
\end{abstract}

Received: October 27, 2017 | Published: November 16, 2017

\section{Introduction}

Pain is a subjective and multidimensional experience, present in the majority of patients undergoing surgical procedures. It can cause suffering, distress and impair quality of life, being associated with emotional, spiritual or personal, social and economic issues of individuals. ${ }^{1}$ Due to the need to treat pain as a discomfort in the postoperative period, criteria were defined to assess the degree of pain, such as the application of a verbal numeric rating scale, where patients are asked to rate their pain. ${ }^{2}$

General anesthesia appeared in the $19^{\text {th }}$ century in order to stabilize the basal conditions and alleviate pain during the intraoperative period. $^{3}$ General anesthesia is defined by virtue of the state of reversible unconsciousness, characterized by amnesia, painlessness, muscle relaxation, loss of sensation and reflexes obtained by specific pharmacological agents, its action is in the central nervous system, taking the patient to a state severe sensorial depression and the disappearance of pain, so that surgical procedures can be performed; administration may be by inhalation or intravenous administration. ${ }^{4}$

Complications related to postoperative pain and anesthesia have a large proportion, and can vary their severity in the short term with minimal pain or in the long term leading to disability or death. The most common complaints in the postoperative period are nausea, vomiting, surgical pain, sore throat, headache, drowsiness, dizziness and thrombosis. It is considered of great importance to the monitoring of these clinical symptoms, since the multiprofessional team needs to develop an evidence-based care plan, and through it is possible to make the patient feel with the least discomfort or pain possible, thus improving quality care and pain management. ${ }^{2}$ The postoperative pain treatment should be performed in an effective way, planned from the mobility of the patient to the choice of medications, taking into account the individual needs of each patient based on institutional analgesia protocols.

In the postoperative period, the patient's admission to the recovery room is comprised between the end of anesthetic administration period and the return of normal patient conditions. The goal of nursing care in the recovery room is pain relief, clinical stabilization and prevention of possible complications. ${ }^{3}$

Need to know how to interpret and measure the pain of the patient was created Visual Analog Scale (EVA) consisting of a scale of measurement of the intensity of pain. The EVA has shown good results in emergencies, recovery rooms and hospitalizations for its low cost, easy handling and understanding and still does not require great efforts of the patient, consists of a ruler of front and back, measuring $10 \mathrm{~cm}$ in diameter and has at the end the number 0 (ZERO) and at the other end the number 10 (DEZ), where 0 means absence of pain and 10 worst pain possible, for its use the patient should point in front of the ruler the level of his pain, after the appropriate note, the nurse observes on the back of the slide the number equivalent to the referred pain of the same. With the application of VAS, care planning and decision-making of nurses will be facilitated, as well as an inquiry into the efficacy and effectiveness of treatment, making patient care 
humanized. ${ }^{5}$. Post-Operative Pain (POP) is common and expected in small, medium and large procedures, the POP should be controlled for the well-being, and for the early recovery of the patient. ${ }^{2}$

Analgesia is used to decrease or control pain. Among the drug classes most used in the treatment of pain are analgesics, nonsteroidal anti-inflammatory drugs, opioids and local anesthetics. ${ }^{6}$ The most commonly used analgesics in the postoperative period are acetaminophen, dipyrone and paracetamol that reduce primary hyperalgesia. This type of analgesia is indicated to reduce lighter and short-term pain. In contrast, the non-steroidal anti-inflammatory drugs (NSAIDs) and opioids are more frequent analgesic agents in the more severe pain, because they act in peripheral and central structures, the most commonly used opioids are Tramadol, Meperidine, Morphine, Propoxyphene. The most frequently used NSAIDs are ibuprofen and acetylsalicylic acid. ${ }^{1}$

Analgesia is a very powerful instrument for pain relief, but several non-pharmacological measures have been used in postoperative patients, although these measures do not replace medications, they help in comfort and in episodes of pain lasting a longer period short, among them are the massage that promotes comfort and produces relaxation, thermal therapies with ice and heat, distraction helps in relieving acute and chronic pain by involving the patient in different things, causing him to forget the pain, another measure not pharmacological is music therapy is a low cost method and brings a pleasant feeling to the patient.

Since pain is the 5th vital sign and the cause of greater discomfort in the postoperative period, the guiding question of this study seeks to answer: how is the management of pain in the immediate postoperative period performed by the nursing team? of this study is to describe pain management in adult patients with visual analogue scale (VAS) submitted to general anesthesia.

\section{Methodology}

It is a study of narrative bibliographic review. The present study analyzed scientific articles in the LILACS database (Latin American and Caribbean Literature in Health Sciences) and SciELO (Scientific Electronic Library Online). For that, the Descriptors in Health Sciences (DeCS) were used: Pain; Analgesia; Post-Operative Care; Visual Analogue Scale and Anesthesia. For this study, articles from 2012 to 2016 were included, with full text availability and free electronic media, in the Portuguese language, that addressed the topic of Pain Management in the postoperative period. Thus, publications without access to the full text online, not free, publications in other languages and studies with children were excluded. Also excluded were articles that were not relevant to the study and did not meet the proposed objective.

For analysis and subsequent synthesis, the articles were systematized through an analysis form, which contained the following items: author, periodical, year, type of study, central objective of the article and conclusions/final considerations.

\section{Results}

We found 512 articles using the descriptors "Pain" and "Analgesia", "Pain" and "Post-Operative Care", "Pain" and "Anesthesia", "Pain" and "Visual Analogue Scale" in the LILACS and SciELO database.

Of these, 450 articles were excluded because they were duplicate studies, studies in animals and other languages, 62 articles were selected for title analysis and abstracts, of which 46 were excluded because they did not fit the proposed theme, 16 articles were for analysis of the full texts, 6 being excluded because they did not adequately address the above mentioned descriptors, thus 10 studies were shown in Table 1 below (Figure 1).

Table I Sample of articles

\begin{tabular}{|c|c|c|c|c|}
\hline $\mathbf{N}^{\circ}$ & Year/Author & Títle & Objetive & Type of study \\
\hline $0 \mathrm{I}$ & 20I4/ BARBOSA et al. ${ }^{7}$ & $\begin{array}{l}\text { Evaluation of pain intensity and } \\
\text { analgesia in patients during the period } \\
\text { of orthopedic surgeries }\end{array}$ & $\begin{array}{l}\text { To evaluate the intensity of pain in } \\
\text { patients in the postoperative period of } \\
\text { orthopedic surgeries. }\end{array}$ & Quantity \\
\hline 02 & $2013 /$ GUIRRO et al. ${ }^{8}$ & $\begin{array}{l}\text { Femoral nerve block: evaluation } \\
\text { of postoperative analgesia in the } \\
\text { arthroscopic reconstruction of the } \\
\text { anterior cruciate ligament }\end{array}$ & $\begin{array}{l}\text { To evaluate whether the use of femoral } \\
\text { nerve block (BNF) associated with spinal } \\
\text { anesthesia would improve the treatment } \\
\text { of postoperative pain in the RLCA. }\end{array}$ & Quantity \\
\hline 03 & 20I2/ RIBEIRO et al. ${ }^{9}$ & $\begin{array}{l}\text { Prevalence of postoperative pain in } \\
\text { elective craniotomy }\end{array}$ & $\begin{array}{l}\text { To identify the presence of pain in } \\
\text { patients undergoing elective craniotomy } \\
\text { and her location. }\end{array}$ & Quantity \\
\hline 04 & $2012 /$ SBRUZZI et al. ${ }^{10}$ & $\begin{array}{l}\text { Transcutaneous electrical nerve } \\
\text { stimulation in postoperative thoracic } \\
\text { surgery: systematic review and meta- } \\
\text { analysis of randomized trials }\end{array}$ & $\begin{array}{l}\text { To evaluate the effects of transcutaneous } \\
\text { electrical nerve stimulation (TENS) } \\
\text { on pain and lung function in the } \\
\text { postoperative period of thoracic } \\
\text { surgeries through a systematic review } \\
\text { and meta-analysis of randomized trials }\end{array}$ & Quantity \\
\hline 05 & 20I2/CANÇADO et al." & $\begin{array}{l}\text { Chronic Post-Caesarean Pain. Influence } \\
\text { of Anesthetic-Surgical Technique and } \\
\text { Postoperative Analgesia }\end{array}$ & $\begin{array}{l}\text { To prospectively evaluate the influence } \\
\text { of different doses of local anesthetic } \\
\text { and opioids in spinal anesthesia, as well } \\
\text { as the use of anti-inflammatory drugs, } \\
\text { in the persistence of pain three months } \\
\text { after cesarean section. }\end{array}$ & Quantity \\
\hline 06 & $2013 /$ sOUZA et al. ${ }^{12}$ & $\begin{array}{l}\text { Knowledge of the nursing team about } \\
\text { behavioral evaluation of pain in critical } \\
\text { patients }\end{array}$ & $\begin{array}{l}\text { To describe the knowledge of the } \\
\text { nursing team about a behavioral } \\
\text { evaluation of pain }\end{array}$ & Quantity \\
\hline
\end{tabular}


Table Continued...

\begin{tabular}{|c|c|c|c|c|}
\hline $\mathbf{N}^{\circ}$ & Year/Author & Títle & Objetive & Type of study \\
\hline 07 & $2012 / \mathrm{KELLER}$ et $\mathrm{al}^{13}$ & $\begin{array}{l}\text { Pain scale: implantation for patients in } \\
\text { the immediate postoperative period of } \\
\text { cardiac surgery }\end{array}$ & $\begin{array}{l}\text { To evaluate the implementation of the } \\
\text { pain scale for postoperative patients of } \\
\text { cardiac surgery }\end{array}$ & Intervention \\
\hline 08 & 2013/MOREIRA et al. ${ }^{14}$ & $\begin{array}{l}\text { Postoperative analgesia: overview of } \\
\text { pain control }\end{array}$ & $\begin{array}{l}\text { Exposing the panorama of postoperative } \\
\text { pain control in hospitalized patients for } \\
\text { general abdominal surgery. }\end{array}$ & Quantity. \\
\hline 09 & $2013 /$ OLIVEIRA et al. ${ }^{15}$ & $\begin{array}{l}\text { Postoperative pain and analgesia: } \\
\text { analysis of records in medical records }\end{array}$ & $\begin{array}{l}\text { To analyze records on pain and } \\
\text { postoperative analgesia in patients' } \\
\text { records. }\end{array}$ & Quantity \\
\hline 10 & 2016/NASCIMENTO et al. ${ }^{16}$ & $\begin{array}{l}\text { Pain management: evaluation of the } \\
\text { practices used by care professionals of } \\
\text { secondary public hospital. }\end{array}$ & $\begin{array}{l}\text { To know the practices used by health } \\
\text { professionals in relation to the pain } \\
\text { management in a public hospital of } \\
\text { secondary level of the north of Paraná. }\end{array}$ & Quantity \\
\hline
\end{tabular}

Source: Rivers; Stachelski, 2017.

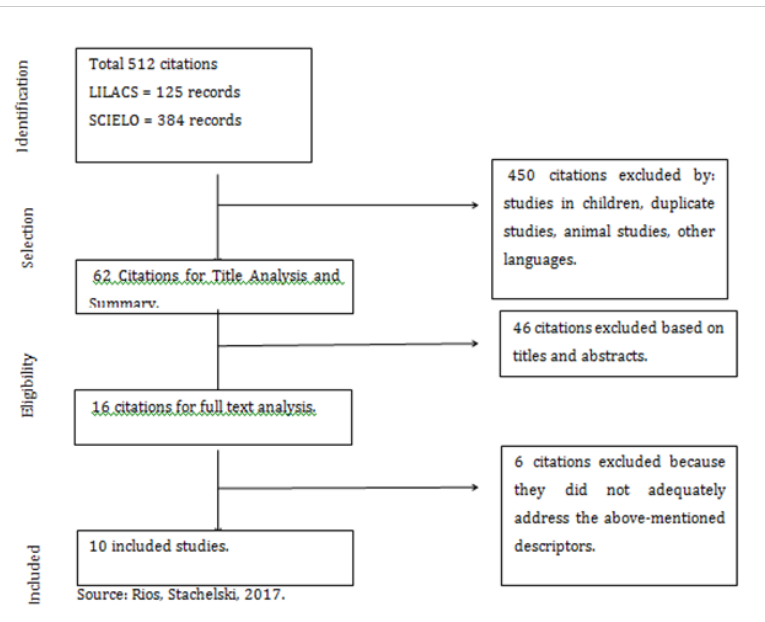

Figure I Flowchart of selection of studies.

\section{Discussion of results}

The findings of this study demonstrated that several factors make it difficult to correctly manage pain, such as underestimating the pain reported by the patient, lack of techniques that ameliorate pain, lack of administration of analgesics, inadequate measurement, lack of recording, pain devaluation as the 5th vital sign, lack of training, training and courses for health professionals with regard to adequate pain management. ${ }^{9}$ Pain is one of the most common complications in the immediate postoperative period, it reduces ambulation and early movement, disrupts sleep and can cause physical exhaustion, fatigue and non-cooperation with treatment and depending on the type of surgical approach generates different levels of pain, this is due to several causes such as: incision, tissue retraction, use of drains after surgery, site of the drains and the inflammatory process. ${ }^{7}$

In the hospital context, there is little evolution in relation to adequate postoperative pain management, which can become chronic when not effectively controlled, impacting the quality of life, and can be characterized as a multidimensional experience, having sensitive aspects, affective, autonomic and behavioral disorders..$^{21}$ The pain does not necessarily depend on the type of surgery, extension or severity, many factors can be triggered like fatigue, depression, anger, fear among others, the use of analgesics is only a part of the treatment process, the multiprofessional strategy comprises actions physical, psychological, social and spiritual characteristics of each patient. In order to adequately manage pain and provide a humanized care to the patient, it is necessary that the pain be thoroughly evaluated at regular intervals, making treatment adjustments whenever necessary. ${ }^{14}$

For an efficient evaluation of the pain by the nursing team in the postoperative period, the patient's verbal report should be considered, considering the subjective pain and evaluation of indirect signs of pain such as anxiety, irritation, behavioral changes and physiological changes such as tachycardia, elevation of blood pressure, dyspnoea and fever. If such manifestations exist, the team of professionals should intervene quickly to avoid complications resulting from inadequate management of pain and worsening of the patient's clinical condition and undesirable processes of pain. ${ }^{9}$ The evaluation of pain should not be neglected the description, pattern, intensity and nature of the same, being reported by the patient and described in a way that is felt, because pain is an unpleasant emotional experience associated with actual or potential harm. In addition, manifestations such as crying, grumbling, shouting and protection of parts of the body should also be considered for such evaluation. ${ }^{19}$ The knowledge and awareness of the health professionals regarding the pain reduce hospitalization time and costs, increasing customer satisfaction. ${ }^{10}$ Having an expressive number of patients with pain, it is necessary to formulate and train routines that will not only help the nursing team, but also the whole multiprofessional team to reduce postoperative pain.

The technological and therapeutic advances have been very present within the hospitals, the professionals' qualification regarding the length of hospitalization and adverse events caused in the postoperative period results in greater patient satisfaction, but little is noticed in relation to the correct management of pain in this a period that is almost always experienced by thousands of patients, uncontrolled pain can become chronic, with a considerable impact on their quality of life. ${ }^{15}$

The American Agency for Research and Quality in Public Health and the American Society of Pain American associations from the year 2000 advocated that pain should be evaluated in a standardized way according to the other vital signs, thus making pain the 5 th vital sign where all patients have the right to adequate pain treatment, besides being a criterion to be used in the care process. ${ }^{16}$

Therefore, systematic evaluations and the use of specific pain scale (VAS) contribute to adequate care and reduction of pain. One of the interventions for pain depending on the outcome of the applied scale is analgesia, which can be considered fundamental for the patient's well-being. ${ }^{7}$ In addition to EVA, we can emphasize the importance 
of the analgesia control scale, which is a method of evaluating the drugs used in the postoperative period, in which records are recorded and the symptoms evolve, thus measuring the visibility of analgesia. ${ }^{13}$

Several health institutions have implemented pain assessment as the 5th vital sign with the application of EVA, an instrument that assigns a characteristic or location through values, aiming to improve ways to relieve pain, providing comfort and well-being to the subject and to avoid that their evaluation is inadequately performed by health professionals. ${ }^{17}$ The analgesic drugs that can be used for the treatment of postoperative pain were classified as: non-steroidal antiinflammatory drugs (NSAIDs), simple analgesics, analgesics and opioids. ${ }^{7}$ Analgesics such as opioids can be administered as a first option in the treatment of postoperative pain, but may increase the incidence of respiratory depression, exaggerated sedation, nausea, vomiting, and may increase hospitalization time and hospital costs. ${ }^{8}$

Due to the adverse reactions of the use of opioids, techniques such as the multimodal management of perioperative pain have been described, consisting of the use of several drugs, with different mechanisms of action, to potentiate the analgesic effect, consequently reducing complications, such as the use of concomitant NSAIDs with other medicines. ${ }^{7}$

Analgesia should be adjusted according to the intensity, characteristics, nature of the pain, as well as the surgical type and size, so the adequate choice of the drug or combinations of drugs is essential for the best postoperative pain treatment. ${ }^{20}$ Multimodal management or combined analgesia can be satisfactory and effective when used in lower doses and in combination with other drugs, resulting in pain relief and prevention of major side effects. ${ }^{11}$ In addition to this technique for the treatment of pain, physical means and interventions related to cognitive behavior, such as educational techniques, relaxation, distractions and music may be used.

It is known that intense pain can influence in a direct and negative way the evolution of the patient in the postoperative period and postpone their recovery, therefore it is indicated to use an adequate pain management, as it contributes to the evolution of the basic physiological functions, avoids side effects harmful effects resulting from the pain process, providing greater comfort and patient satisfaction. ${ }^{9}$

Patients submitted to surgical procedures experience moderate to severe pain, even with the development of new drugs and the use of new analgesic techniques, so according to Couceiro18 the treatment of pain in the post- reduces morbidity and, if properly applied, leads to better incisional healing, reducing hospital costs, cognitive alteration and chronic or persistent pain.

The nursing team spends most of the time with the patient, being present at all times of their hospitalization, it is important that they recognize the signs of pain so that they can intervene safely and correctly in pain relief, in order to solve the problem. ${ }^{12}$ The nurse stands out as an important professional in the evaluation of these factors, which provide a contribution and incentive for the adequacy of treatment. ${ }^{9}$

\section{Final considerations}

The multidisciplinary team must participate actively and humanized in the treatment of pain, highlighting the important role of nursing in appropriate management, the nurse is a transforming agent and disseminator of care. The subjectivity of the patient's pain report should be valued, taking into account their complaints and requests, corroborating the development of trust and communication links with the patient, as well as the evaluation of the biopsychosocial status, because at this moment the patient is fragile.

In order for the correct postoperative pain management to occur, it is important to emphasize the importance of standardization of routines, training and training involving the entire team, since the implementation of the protocol for pain management depends on the correct evaluation of the pain, emphasizing that the nursing is at the edge of the bed being the patient's first contact. In this context, it is believed that EVA can contribute in an effective way, in order to facilitate the measurement of pain, making it possible to choose the best management, being it with analgesic or physical behavioral measures to be performed at that moment. With a well-established routine and adequate protocols, hospital costs are reduced, bringing greater satisfaction to the patient.

\section{Acknowledgments}

None.

\section{Conflicts of interest}

The authors declare no conflicts of interest.

\section{Funding}

None.

\section{References}

1. Menezes MGV, Ribeiro CJN, Nascimento FS, et al. Dor pós-operatória e analgesia em pacientes submetidos á pinçamento de aneurisma cerebral não roto. Rev Dor. 2017;18(1):27-31

2. Tennant I, Augier R, Sykes CA, et al. Complicações Pós-operatórias menores relacionadas à anestesia em pacientes de cirurgias eletivas ginecológicas e ortopédicas em um Hospital Universitário de Kingston Jamaica. Revista Brasileira de Anestesiologia. 2012;62(2):193-198.

3. Oliveira Junior NJ. Noções básicas para Assistência de Enfermagem em Centro Cirúrgico, Sala de Recuperação e Centro de Material e Esterilização. 1st edn, Moriá, Porto Alegre, Brazil. 2012.

4. Timby BK. Conceitos e habilidades fundamentais no atendimento de enfermagem. (10th edn), Artmed, Porto Alegre, Brazil. 2014.

5. Bottega FH, Fontana RT. A dor como quinto sinal vital:utilização da escala de avaliação por enfermeiros de um hospital geral. Textocontexto - enferm, Florianópolis. 2010;19(2):283-290.

6. Teixeira PAP, Amaral LT, Almeida LRM, et al. Manejo da dor pósoperatória:uma revisão bibliográfica. Revista de Medicina e Saúde de Brasília. 2014;3(1):85-93

7. Barbosa MH, Araújo NF, Silva JAJ, et al. Avaliação da intensidade da dor e analgesia em pacientes no período pós-operatório de cirurgias ortopédicas. Esc Anna Nery. 2014;18(1):143-147.

8. Guirro UBP, Tambara EM, Munhoz FR. Bloqueio do nervo femoral:avaliação da analgesia pós-operatória na operação de reconstrução artroscópica do ligamento cruzado anterior. Ver Bras Anestesiol. 2013;63(6):483-491.

9. Ribeiro MCO, Pereira CU, Sallum AMC, et al. Prevalência de dor no pós-operatório de craniotomia eletiva. Arq Bras Neurocir. 2012;31(3):124-127.

10. Sbruzzi G, Silveira AS, Silva DV, et al. Estimulação elétrica nervosa transcutânea no pós-operatório de cirurgia torácica:revisão sistemática e metanálise de estudos randomizados. Rev Bras Cir Cardiovasc. 2012;27(1):75-87. 
11. Cançado TOB, Omais M,Ashmawi HA, et al. Dor crônica pós-cesariana. Influência da técnica anestésico-cirúrgica e da analgesia pós-operatória. Rev Bras Anestesiol. 2012;62(6):762-774.

12. Souza RCS, Garcia DM, Sanches MB, et al. Conhecimento da equipe de enfermagem sobre avaliação comportamental de dor em paciente crítico. Rev Gaúcha Enferm. 2013;34(3):55-63.

13. Keller C, Paixão A, Moraes MA, Rabelo ER, et al. Escala da dor:implantação para pacientes em pós-operatório imediato de cirurgia cardíaca. Rev Esc Enferm USP. 2013;47(3):621-625.

14. Moreira L, Truppel YM, Kozovits FGP, et al. Analgesia no póscirúrgico:panorama do controle da dor. Rev Dor São Paulo. 2013;14(2):106-110.

15. Oliveira RM, Leitão IMTA, Silva LMS, et al. Dor e analgesia pósoperatória:analise dos registros em prontuários. Rev Dor São Paulo. 2013;14(4):362-365.

16. Nascimento LA, Cardoso MG, Oliveira AS, et al. Manuseio da dor: avaliação das praticas utilizadas por profissionais assistenciais de hospital publico secundário. Rev Dor São Paulo. 2016;17(2):76-80.
17. Leão MGS, Neta GPM, Coutinho LI, et al. Análise comparativa da dor em pacientes submetidos à artroplastia total do joelho em relação aos níveis pressóricos do torniquete pneumático. Rev Bras Ortop. 2016;51(6):672-679.

18. Couceiro TCM, Lima LC, Couceiro LM, et al. Lidocaína intravenosa no tratamento da dor pós-operatória. Rev Dor São Paulo. 2014;15(1):5560.

19. Filho GSF, Caixeta LR, Stival MM, et al. Dor aguda:julgamento clínico de enfermagem no pós-operatório de cirurgia cardíaca. Rev Min Enferm. 2012;16(3):400-409.

20. Panazzolo OS, Siqueira FD, Portella MP, et al. Avaliação da dor na sala de recuperação pós-anestésica em hospital terciário. Rev Dor São Paulo. 2017;18(1):38-42.

21. Muñoz RLS, Rocha GES, Garcia BB, et al. Prevalência de dor e adequação da terapêutica analgésica em pacientes internados em um hospital universitário. Medicina (Ribeirão Preto) 2015;48(6):539-548. 